\title{
Sustaining Cross-Timbers Forest Resources: Current Knowledge and Future Research Needs
}

\author{
Omkar Joshi ${ }^{1, *(\mathbb{D},}$, Rodney E. Will ${ }^{1}$, Chris B. Zou ${ }^{1}$ and Gehendra Kharel ${ }^{2} \mathbb{C}$ \\ 1 Department of Natural Resource Ecology and Management, Oklahoma State University, Stillwater, \\ OK 74078, USA \\ 2 Department of Environmental Sciences, Texas Christian University, Fort Worth, Texas, TX 76129, USA \\ * Correspondence: omkar.joshi@okstate.edu
}

Received: 26 July 2019; Accepted: 23 August 2019; Published: 29 August 2019

\begin{abstract}
The Cross-Timbers region of the United States, situated in the southern Great Plains along the western edge of the eastern deciduous forest, was historically Quercus-dominated open forest interspersed with tallgrass prairie and shrubs communities. The historical structure of the CrossTimbers forests in this region has been altered, mainly due to fire exclusion, such that the current structure is closed-canopy and includes a midstory of fire-intolerant species. This change has reduced many of the important ecosystem services provided. This paper synthesizes existing literature on the Cross-Timbers with the aim of summarizing the current state of Cross-Timbers management related to sustaining ecosystem services and identifying potential research topics and directions needed. Specifically, we consider the ecological, management, and socio-economic issues. In addition, we theorize how the adoption of active forest management will affect ecosystem services and structure of the Cross-Timbers forests.
\end{abstract}

Keywords: social science research; forested ecosystems

\section{Introduction}

The Cross-Timbers region spans an area of approximately 8 million hectares in the southern Great Plains of the United States, extending from southern Kansas through central Oklahoma, and into Texas [1] (Figure A1). Approximately 4.5 million ha of the Cross-Timbers is in Oklahoma and the majority of the remaining 3.5 million ha is in Texas [2]. This region consists of forest historically dominated by post oak (Quercus stellata) and blackjack oak (Q. marilandica) of variable tree densities interspersed with patches of tallgrass prairie and shrubland of varying sizes. Cross-Timbers trees are relatively short, with mature trees reaching approximately $15 \mathrm{~m}$ in height [3-5]. When measured in the mid-1950s the Cross-Timbers in Oklahoma was largely an open forest $\left(9.5 \mathrm{~m}^{2} \mathrm{ha}^{-1}\right.$ basal area and 65 trees $\left.\mathrm{ha}^{-1}\right)$ and dominated by post oak (55\% basal area and $53 \%$ tree ha $\left.{ }^{-1}\right)$ and blackjack oak $\left(33 \%\right.$ basal area and $39 \%$ trees ha $\left.{ }^{-1}\right)[6]$.

The Cross-Timbers region includes portions of metropolitan Tulsa and Oklahoma City in Oklahoma and Dallas-Fort Worth in Texas and the high and increasing population is a major challenge for natural resource management in the Cross-Timbers [7]. Furthermore, the area is important for agriculture and also provides recreational opportunities due to the urban-rural interface, diverse wildlife, relatively abundant water, and the attractive aesthetics associated with this complex landscape [1].

However, most of the land area is not actively managed and many places are experiencing degradation of natural resources which may reduce ecosystem services important for the people within the region $[1,8,9]$. Largely due to fire exclusion, the forest is undergoing an increase in post oak basal area and encroachment by fire-intolerant trees such as eastern redcedar (Juniperus virginiana) which is leading to densification and mesophication [4]. These changes are disrupting ecosystem 
services by reducing wildlife habitat for savanna and woodland species [10], reducing livestock grazing opportunities [9], increasing the risk of wildfire [11], reducing water yield to streams and reservoirs [12,13], reducing understory productivity and biodiversity [14], and potentially reducing recreational opportunities. More broadly, the sustainability of the Cross-Timbers region to provide ecosystem services is endangered due to cumulative effects of natural and human induced factors including climate variability, invasive and encroaching species, changes to historic disturbance regimes, and urbanization [1].

Despite its ecological significance and importance to people living within the region, there is little information about the dynamics of the mostly privately-owned Cross-Timbers forests and the social factors that motivate individual owners for its management. Approximately of $90 \%$ of forest land across Oklahoma, Texas, and Kansas is privately owned with the $10 \%$ of public ownership predominantly in National Forest lands east of the Cross-Timbers region [15]. Given that corporate ownership of forest lands in Texas and Oklahoma ( $20 \%$ of total forest land) is focused in the more productive, pine growing regions east of the Cross-timbers, the private ownership in the Cross-Timbers is heavily dominated by small, family forest landowners [16].

Research directly related to the management of the Cross-Timbers forests is limited. Most of the ecological research within Cross-Timbers forests focused on government-owned areas with either low productivity or atypical management regimes such that outcomes are not directly transferable to private landowners who own small, fragmented, and often highly disturbed parcels. Although a recent social science inquiry revealed that stakeholders, including the landowners, are willing to implement active management strategies [7], existing knowledge on the privately owned portion of the Cross-Timbers as well as the desire of people to manage them are largely unknown. The Cross-Timbers generally lacks traditional wood and fiber markets. Therefore, management needs and logistics of the Cross-Timbers are different from many other forested regions. As such, important challenges related to the Cross-Timbers' management are to explore alternative market opportunities $[7,15]$ and to understand social factors to facilitate sustainable management of the Cross-Timbers and the valuable ecosystem services it provides. Therefore, the main objectives of this review are to (1) give a brief history of the Cross-Timbers to provide context regarding the historical ecosystem services relative to their current degraded condition, (2) discuss the current state of the Cross-Timbers' management related to sustaining ecosystem services, and (3) identify some potential research topics and directions needed to better manage the Cross-Timbers for ecosystem services. Our goal is to provide an impetus and starting point for needed ecological, management, and social research for private lands in the Cross-Timbers to ultimately improve sustainable management for the full range of ecosystem services.

\section{Methods}

In this study, we performed a systematic review of literature regarding active management of the Cross-Timbers. We performed the literature search using the electronic literature database Scopus (https://www.scopus.com/) up to 31 December 2018.

First, we searched the title, abstract, and keywords using the search criteria: "cross-timber*" OR "cross timber*". This search criteria resulted in a total of 103 documents published between 1969 and 2018, of which 94 were research papers, four were reports, two were review papers and there was one each of a book chapter, conference paper, and erratum. Within these 103 documents, we conducted a search with location specific keywords 'Kansas', 'Oklahoma', and 'Texas' to narrow down the search to these three states where the Cross-Timbers forests are located. This search criterion resulted in 95 articles (86 research papers, four reports, two review papers, and one each of a book chapter, conference paper, and erratum). These 95 articles broadly highlighted issues pertaining to grassland management, agricultural commodities, natural gas and other power generation activities, as well as ecosystem service related issues.

Since this review was focused on sustaining Cross-Timbers forest resources, we selected 41 articles that highlighted existing knowledge on ecosystem services in the Cross-Timbers. Also, we reviewed 
other publications that were cited by these articles or were pertinent to the Cross-Timbers region of the southern Great Plains. After careful review of the content, we categorized the existing literature into three broad categories: (a) ecological research; (b) management related research; and (c) social science research. The ecological research highlights fundamental aspects of ecology including the species regeneration, forest composition, forest productivity, etc. The management-oriented research highlights the available information related to use of prescribed fire and herbicides as management tools for active management. The social science research summarizes public perceptions on active management that involves prescribed fire, forest thinning, and herbicide uses.

\section{History and Current Condition of the Cross-Timbers}

The Cross-Timbers has been long influenced by humans as the current vegetation species assemblages established at approximately the same time as the occupation of the area by Native Americans approximately 4000-7000 before present (B.P). Ref. [17] who used fire to maintain areas of the forests to achieve low tree density and abundant understory layers. Early reports by European-Americans portray the Cross-Timbers region in the 1700s and early 1800s as having areas where densely occurring, small stature trees made it difficult to travel, but also as having an open, park-like structure [18]. Given these contrasting accounts, the forest condition before the European-American settlement was likely a mix of dense forest, woodland, and savanna with a probable reporting bias of historical accounts to favor mentioning dense forests as they posed a memorable and notable challenge to travel. During European-American settlement, forests were high-graded, i.e., the best trees were harvested leaving less desirable trees, and productive areas were converted to agriculture [18].

Before European-American settlement, periodic, dormant-season, surface fires were common in the region with return intervals measured from 2.9-6.7 years [19-22]. These relatively frequent fires maintained a more open forest structure dominated by fire-tolerant post oaks and blackjack oaks [23]. Fires were largely excluded beginning between the mid-19th to mid-20th century. For instance, at Purtis Creek State Park in Texas, fire scars within the tree ring record indicated that regular and frequent fires occurred until the 1850s after which only four fires occurred, all in the early 1900's [24].

Fire exclusion led to the conversion of open-woodland and grassland patches to closed-canopy forests that include fire-intolerant, mesic hardwoods such as Ulmus spp., Carya spp., and Celtis spp. $[4,23]$ as well as the encroachment of the more xeric, but fire-intolerant Juniperus spp. (eastern redcedar, Juniperus virginaia, in Kansas, Oklahoma, and north Texas; Ashe juniper, Juniperus ashei, in parts of central Texas). When re-measured during 2007-2008, the Cross-Timbers plots originally measured by [6] in the 1950s had increased in tree basal area from 9.5 to $18.5 \mathrm{~m}^{2} \mathrm{ha}^{-1}$ and increased in tree density from 65 to 109 trees ha ${ }^{-1}$ [23]. While post oak increased from 55 to $59 \%$ of basal area, blackjack oak decreased in absolute numbers and decreased from 33 to $15 \%$ of basal area. Reductions in blackjack oak also have been documented by others $[4,25]$ and may stem from greater susceptibility to Biscogniuxia spp. (Hypoxylon canker). Recruitment of oak within the forest matrix [26] and into areas without previous tree cover [27] was correlated to periods of drought.

Between the 1950s and 2008, eastern redcedar basal area in the Rice and Penfound plots increased from 0.1 to $2.7 \mathrm{~m}^{2} \mathrm{ha}^{-1}$ and from 0.7 to 23.9 stems ha $^{-1}$ [23] with most of the establishment of eastern redcedar occurring after the 1950s as estimated from the ring counts of existing trees [4,28]. Similar to eastern redcedar, mesic hardwoods began to enter the overstory beginning in the 1950s [4]. A fire return interval of between 5 and 10 years appears to be sufficient to purge the understory of mesic hardwoods and eastern redcedar [29] as the trees are still small enough to kill with prescribed fire. For instance, it took 9 years for eastern redcedar to reach breast height $(1.37 \mathrm{~m})$ when growing within Cross-Timbers forest [4].

This change in forest structure and composition is causing profound disruption to ecosystem services. The overall increase in canopy cover, eastern redcedar in particular, has caused a reduction in herbaceous understory productivity and biodiversity [14]. This reduces wildlife habitat for economically 
and recreationally important species such as white-tailed deer (Odocoileus virginianus), wild turkey (Meleagris gallopavo), and northern bobwhite (Colinus virginaianus), as well as woodland and prairie obligate species $[1,10]$. Increased forest density and eastern redcedar encroachment reduce recreational opportunities associated with hunting and wildlife viewing as well as activities that include access and movement within a more open forest. Along with the loss of wildlife habitat, forest densification is causing the loss of grazing potential as grasses are shaded out by increased forest canopy cover. Additionally, reduced water yield for human and ecological use is anticipated as the herbaceous understory is being displaced by eastern redcedar $[13,30]$.

These changes in forest composition and structure increase the risk of wildfire. The addition of mesic hardwoods and eastern redcedar suppresses understory fine fuels produced by herbaceous plants and the tree leaf litter does not burn as well which reduces the potential use of prescribed fire. However, the infilling of eastern redcedar increases the risk of wildfire because eastern redcedar foliage is extremely flammable during drought and during conditions conducive to wildfire. For instance, canopy cover analysis suggested that eastern redcedar encroachment in the north-central region of the Cross-Timbers forest has increased available fuel loading by $38 \%$ through the addition of eastern redcedar foliage and small branches [11]. This increased fuel load elevates the risk of uncontrolled and damaging wild fires that reach the tree canopies and which do not have an historical analog in the Cross-Timbers, likely leading to novel successional pathways [28].

\section{Status of Existing Research}

\subsection{Ecological Research}

Much of what we know about the ecology of the Cross-Timbers is focused on unmanaged or lightly managed areas of ecological significance that are often controlled by government entities or non-governmental organizations $[3,19,20,22]$. While these studies provide insightful information on the ecological status of the Cross-Timbers, they do not represent the vast majority of land ownership within the Cross-Timbers, which is privately held. Notable exceptions are the Rice and Penfound plots $[6,23]$ and work done looking at parcels held in trust by the Bureau of Indian Affairs $[4,11]$.

Since privately owned land is rarely burned, undergoes fragmentation and urbanization, and suffers haphazard disturbance, conclusions based on existing ecological research may not be directly transferable to private landowners. For example, Ref. [31] found that oak species were regenerating in gaps and predicted no change in forest composition at the frequently burned Keystone Ancient Forest Preserve. However, the seedling layer of nearby non-burned private lands were dominated by Celtis spp., Ulmus spp., and Carya spp. [4] with these faster growing [11], mesic species likely more readily filling gaps created by overstory tree mortality in the absence of fire. Likewise, focus on lands that are frequently burned as part of well-informed management by government entities or non-governmental organizations might miss the opportunity to address the Juniperus spp. encroachment issues, which are widespread on less intensively managed private lands [32]. To successfully manage both public and private lands in the Cross-Timbers, the full range of initial starting conditions must be considered and our management tailored accordingly (see 'potential pathways' section below).

The productivity of the Cross-Timbers is highly variable due to large heterogeneity in site quality. Analysis of 116 Natural Resource Inventory plots across Oklahoma indicated tree volumes ranged from 14.9 to $102.5 \mathrm{~m}^{3} \mathrm{ha}^{-1}$ and annual growth rate ranged from 0.0 to $4.5 \mathrm{~m}^{3} \mathrm{ha}^{-1} \mathrm{y}^{-1}$ [33]. A fairly productive site near Lake Thunderbird, Oklahoma produced approximately $1.5 \mathrm{dry} \mathrm{Mg} \mathrm{ha}{ }^{-1} \mathrm{y}^{-1}$ [34].

Another limitation of much of the ecological research in Cross-Timbers forests is that it tends to focus more on lower productivity sites as these are often the least disturbed and most inaccessible such that they became protected areas or areas of special interest. Consequently, the Cross-Timbers forest is often considered one of the least altered forest types in the United States [5]. There are areas of 'old growth' or 'ancient forests' in the Cross-Timbers that generally correspond to the combination of steep slopes and infertile soils [5]. These old forests contain some 200-400 year-old trees, and are relatively 
undisturbed, except for the interruption of the historical, recurrent surface fire regime. This focus on old forests has likely resulted in a general perception that the productivity of the Cross-Timbers is marginal and the Cross-Timbers is of low value. In contrast, the majority of Cross-Timbers forests are privately owned, more productive, and more disturbed which likely accelerates the densification, mesophication, and redcedar encroachment processes.

\subsection{Management Related Research}

Given the low perceived value of Cross-Timbers forests for traditional economic uses, i.e., timber and fiber, timber management related research is relatively rare. The most researched aspect of management is the impact of prescribed fire. In [29] it was found that prescribed fires with fire frequencies ranging between zero to five fires per decade, did not affect the oak component, but two fires per decade were sufficient to keep fire-intolerant species from establishing in the understory. Research at the same site indicated that $\mathrm{C} 3$ graminoids and forbs increased with fire frequency but fire frequency did not affect understory woody plant, C4 graminoid, or legume abundance [35]. In [36] it was found that a fire return interval of two years reduced soil organic matter and carbon but did not affect soil nutrients.

In addition to research on fire return interval, another vein of management research has been brush control to enhance grazing and wildlife potential [37]. For instance, Ref. [38] studied the use of herbicides and burning to reduce overstory hardwood trees. Woody plant specific herbicides increased herbaceous growth with triclopyr having a greater benefit to grasses and tebuthiuron having a greater benefit to forbs. Burning for several years after herbicide application did not have a large effect on herbaceous growth, but prevented later encroachment of eastern redcedar. Ref. [10] compared wildlife habitat use between control areas and experimental plots, and identified that controlled burning and herbicide applications provide favorable habitat for white-tailed deer. Study results suggested that heterogeneous landscapes created through the use of herbicides and prescribed burning can enhance ecosystem services related to wildlife as well as economic returns related to grazing and hunting for landowners in the Cross-Timbers. Ref. [39] analyzed how herbicide use for brush reduction influenced breeding bird populations in the fall and winter seasons in the Cross-Timbers region. The research suggested that excessive use of herbicide for brush management, which would lead to elimination of oak forest, would likely reduce overall richness of nongame bird species. Likewise, conversion of Cross-Timbers forests to grasslands through reduction of the woody plant components would reduce the population of reptiles and amphibians [40].

\subsection{Social Science Research}

The third category of research focused on the social challenges associated with better management of the Cross-Timbers. Ref. [41] utilized a multi-year linear programming model to develop alternative management objectives with the goal of generating the highest economic return in an efficient manner. The study results suggested that raising livestock, property lease for recreation and hunting, coupled with alternative management practices such as herbicide and prescribed fire would likely provide the highest net economic returns and increase land resource value by $40 \%$. Our literature review suggested that research on social acceptance for active management is particularly sparse. Although not specific to the Cross-Timbers, Ref. [42] conducted research to understand public views about prescribed fire as a management tool. The study findings suggested that liability related concerns were the major reason for lack of enthusiasm for using prescribed fire among Oklahoma residents. Recent social science research found that the general public in the southern Great Plains of the United States, including the Cross-Timbers region, generally prefer mosaic landscapes created through the interaction of fire and grazing [43]. Despite interest in active management, risk and liability issues become major impediments for conducting prescribed burns in this region [44]. While these studies provide some insights into landowner behaviors and socio-economic challenges, the primary focus of the work was geared toward grassland restoration in the Cross-Timbers region. 
In recent years, some efforts have been made to understand how stakeholders view management interventions involving the combination of prescribed fire, thinning, and herbicide use in the forested region of the Cross-Timbers [7]. The authors found that the presence of healthy and resilient forests in the region is likely to motivate landowners and other stakeholders to adopt active management practices because they were thought to result in the best opportunities to generate revenues [7]. However, stakeholders thought that the financial burden associated with the practices and the threats related to the risk of escaped fire were a concern for successful implementation of such practices. With a similar line of inquiry, Ref. [15] identified how stakeholders think about potential markets that may bring employment and other income generation activities to the Cross-Timbers. The authors found that abundant natural resources and associated ecosystem services may provide opportunities for non-traditional markets in the region. Possibilities for alternative markets are yet to be fully explored and the lower quality resources and lack of enthusiasm among investors are obstacles to this effort.

\section{Potential Pathways}

There are several socio-economic impediments to successful implementation of active forest management. As outlined in the Oklahoma Forest Action Plan, land use parcelization in the Cross-Timbers has created more ownerships with smaller landholdings. As a result, forest management is likely expensive to conduct in smaller forested parcels due to diseconomies of scale. Also, there is not a strong market given the generally low value of post oak and blackjack oak and long distance to manufacturing facilities. Therefore, owners may need to accept the risk and costs of prescribed fire and the expense of non-commercial thinning to restore forest structure and improve ecosystem services.

Areas of the Cross-Timbers that currently still reflect the 'historical' condition, i.e., savanna and woodland dominated by post oak and the blackjack oak with a diverse and abundant understory, can be maintained by prescribed fire. Combining thinning and prescribed fire can convert the 'current' condition, i.e., closed-canopy forest with a midstory dominated by eastern redcedar and mesic hardwoods, back to the 'historical' condition. This may improve ecosystem services related to wildlife habitat for species such as deer, turkey, and quail, improve water yield to streams, improve grazing conditions for livestock, and lower the risk of wildfire (Figure A2). However, there are management scenarios that would result in novel forest conditions.

Reinstatement of prescribed fire without thinning (Pathway 1, Figure A2) will reduce the midstory and eventually eliminate many of the mesic hardwood stems. Larger, existing eastern redcedar will likely persist because eastern redcedar stems taller than $3 \mathrm{~m}$ typically survive prescribed fire [45] and the fuel condition underneath larger eastern redcedar stems is dominated by duff rather than fine fuels that readily burn. This burning-only management will improve some ecosystem services by increasing the understory abundance and diversity, but the most likely outcome will be a closed-canopy forest consisting of oak and eastern redcedar. The largest impediment to this management regime is the reluctance of landowners to employ prescribed burning due to social factors or liability concerns. In addition, the ecological effects of reintroducing prescribed fire to these systems and the best timing and weather conditions for burning to best achieve desired results is uncertain.

Thinning without using prescribed fire will increase understory productivity in the short term which will cause a transient increase for several desired ecosystem services (Pathway 2, Figure A2). The lack of fire will likely increase the future dominance of eastern redcedar and mesic hardwoods as they comprise the majority of midstory and understory stems [11]. The largest impediment to this management pathway is the lack of markets for harvested stems. Likewise, the ecological response of this management pathway is not certain and may result in undesirable long term responses, i.e., greater redcedar dominance. Additionally, the best specific practices to use for thinning Cross-Timbers stands are not certain.

Regeneration of the Cross-Timbers can be accomplished using techniques such as shelterwood which is successfully used in oak forests in other regions (Pathway 3, Figure A2). However, prescribed fire needs to be incorporated in the management to restore the historical structure. Without including 
prescribed fire, the ultimate condition will likely resemble the 'current' condition or even one with increased dominance by mesic hardwoods. Because eastern redcedar does not stump sprout and is considered shade-intolerant, its ability to reestablish after a shelterwood might be reduced depending on how quickly a closed-canopy develops. Impediments for this management pathway include social and liability issues related to prescribed fire, lack of markets, and lack of a complete understanding related to regeneration dynamics of post oak and blackjack oak in the Cross-Timbers region.

\section{Future Research Direction}

Given the disruption of historical ecosystem services in the Cross-Timbers and the relatively sparse research to guide management and restoration of these services, there are a number of important research needs that should be pursued.

\subsection{Ecological Needs}

While ecological research in the Cross-Timbers is relatively abundant compared to research focused on the management and social aspects, additional ecological research is needed on more disturbed, higher productivity areas to better understand the functioning of the majority of lands in the Cross-Timbers. Changes in species composition and forest structure need to be better understood in the context of wildlife habitat, biodiversity, wildfire risk, and water yield. Understanding of productivity and its relationship to site factors is needed to quantify woody biomass production and carbon sequestration. Fortunately, the United States Forest Service is nearing completion of the first round of measurement for their Forest Inventory and Analysis in the Cross-Timbers region of Oklahoma and Texas which will lead to a better understanding of forest composition, structure, and stocking. Given the indications that blackjack oak is declining, research into the extent of decline and its causes are needed should we want to maintain or restore the traditional composition of the Cross-Timbers. Given that the Cross-Timbers is currently in a transition state due to exclusion of the historical surface fire regime, understanding the current trajectory of succession and vegetation recovery from future disturbances such as wildfire and severe drought is needed.

\subsection{Management Related Needs}

Previous studies provide guidance related to herbicides and prescribed burning to improve wildlife habitat by enhancing understory vegetation and forage productivity. However, no research to our knowledge has focused on purposefully regenerating the oak component which could provide benefits of woody biomass harvest, improved wildlife habitat for forest and woodland species, increased water yield and quality, and reduced risk of wildfire. While previous information on oak regeneration into naturally formed gaps $[31,46]$ is instructive regarding the possible initial response to a shelterwood, the suddenness of gap formation with tree harvesting as well as the response of an understory composed of oak, eastern redcedar, and mesic hardwoods typical of private lands is not known. Research on the silviculture of oak ecosystems in the eastern United States is expansive and, in many ways, pertinent to the Cross-Timbers forest. However, the lower precipitation and more marginal conditions within the Cross-Timbers present additional obstacles for their unmodified adoption. Managers likely need to consider that regeneration from seed is less frequent and the lower overall productivity when adapting practices from other regions.

Given the increase in eastern redcedar and mesic hardwoods, an understanding of how thinning, gap creation, and general canopy disturbance affect the release of these species, as well their competitive interactions with oaks, is needed. A better understanding of the application of prescribed fire in the Cross-Timbers to achieve desired objectives is needed as in many cases the current and likely future forest conditions have no previous analog. Finally, while average productivity of the Cross-Timbers forests is often lower than further east, there is large variation in the Cross-Timbers region with some areas being extremely productive [6]. No research to our knowledge has adequately determined site 
factors related to high productivity which aid identification of areas that might serve as non-competing hot spots for traditional and non-traditional forest products.

\subsection{Social Science Related Needs}

Although some efforts have been made to understand the broader economic prosperity and environmental conservation in the Cross-Timbers, minimal efforts have been made to understand the value of cultural ecosystem services (e.g., recreation, hunting, and cultural values). In addition, little has been done to know whether landowners would engage in management activities to restore or improve ecosystem services. As family forest landowners own a majority of the Cross-Timbers, it is imperative to understand their perceptions. Therefore, future research that aims to understand landowner perceptions and willingness to accept (WTA) for management practices is essential.

As management for ecosystem services is based on a holistic management approach that integrates natural and socio-ecological processes [47], it is crucial to understand the cumulative impact of both processes. To this end, an agent based modelling ( $\mathrm{ABM}$ ) research approach can integrate how physical processes and social events can influence the land management decisions in the Cross-Timbers [48]. In addition, ABM tools can simulate both processes over a defined time horizon in the future [48]. In particular, integrating stakeholder perceptions of better management of the Cross-Timbers with the information on tree growth, market opportunities, and watershed management, among others, can provide a complete picture of the future state of the Cross-Timbers.

Finally, research efforts may not result in best practices unless they are linked with outreach and extension. While some outreach outlets in the form of fact sheets, reports, workshops, or demonstrations are available, a targeted strategy is suggested to serve landowners with diverse interests and motivations. As [49] highlighted, given the diversity in opinions and management objectives, a one size fits all formula is not effective in landowner education. Rather, targeted programs need to be designed for each subset of landowners having similar opinions and management objectives. As such, more market oriented research is needed.

\section{Conclusions}

In this review study, we used a systematic approach to document existing research that highlights the historical significance of the Cross-Timbers and that passive management has led to the loss of traditional ecosystem services associated with these forests. Our synthesis suggests that while management of the Cross-Timbers has been a topic of contemporary research, the focus has been biased towards public lands, lower productivity sites, and those with areas of special interest. Given that Cross-Timbers forests are highly variable in terms of productivity, further research is needed to address management challenges and bottlenecks in the productive areas that may provide a variety of provisioning ecosystem services. Given the lack of current research focus, further investigation on social acceptability, stakeholder perceptions, and willingness to pay is warranted to facilitate management that often comes at a cost to landowners.

Funding: The APC was funded by McIntire Stennis projects.

Acknowledgments: This work was supported by the USDA National Institute of Food and Agriculture-McIntire Stennis project grant numbers (OKLO3042, OKL0 3151, OKLO 3152) and the Division of Agricultural Sciences and Natural Resources at Oklahoma State University.

Conflicts of Interest: The authors declare no conflict of interest. 
Appendix A

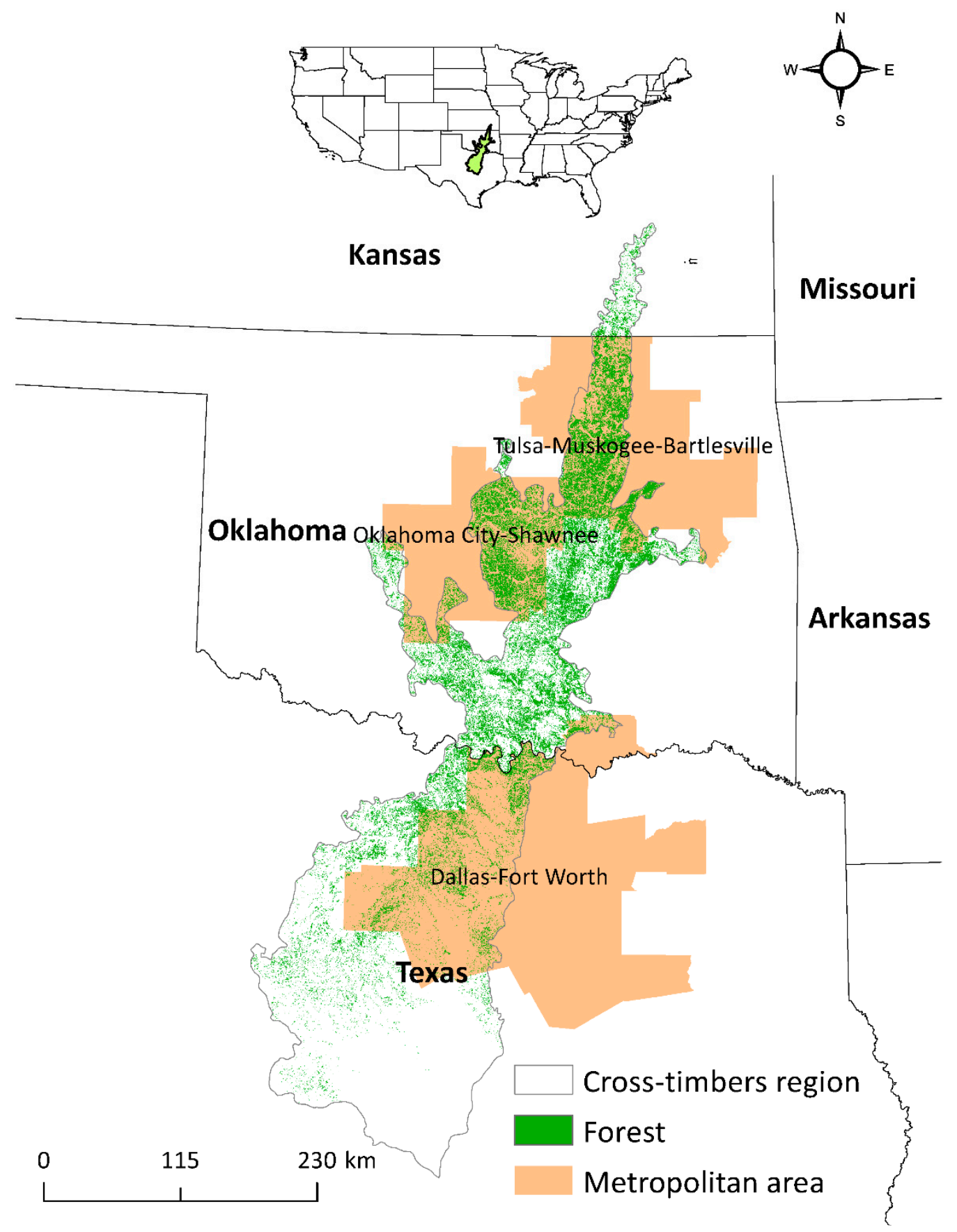

Figure A1. Study area showing distribution of Cross-Timbers oak forests and woodlands, and locations of major metropolitan areas. 


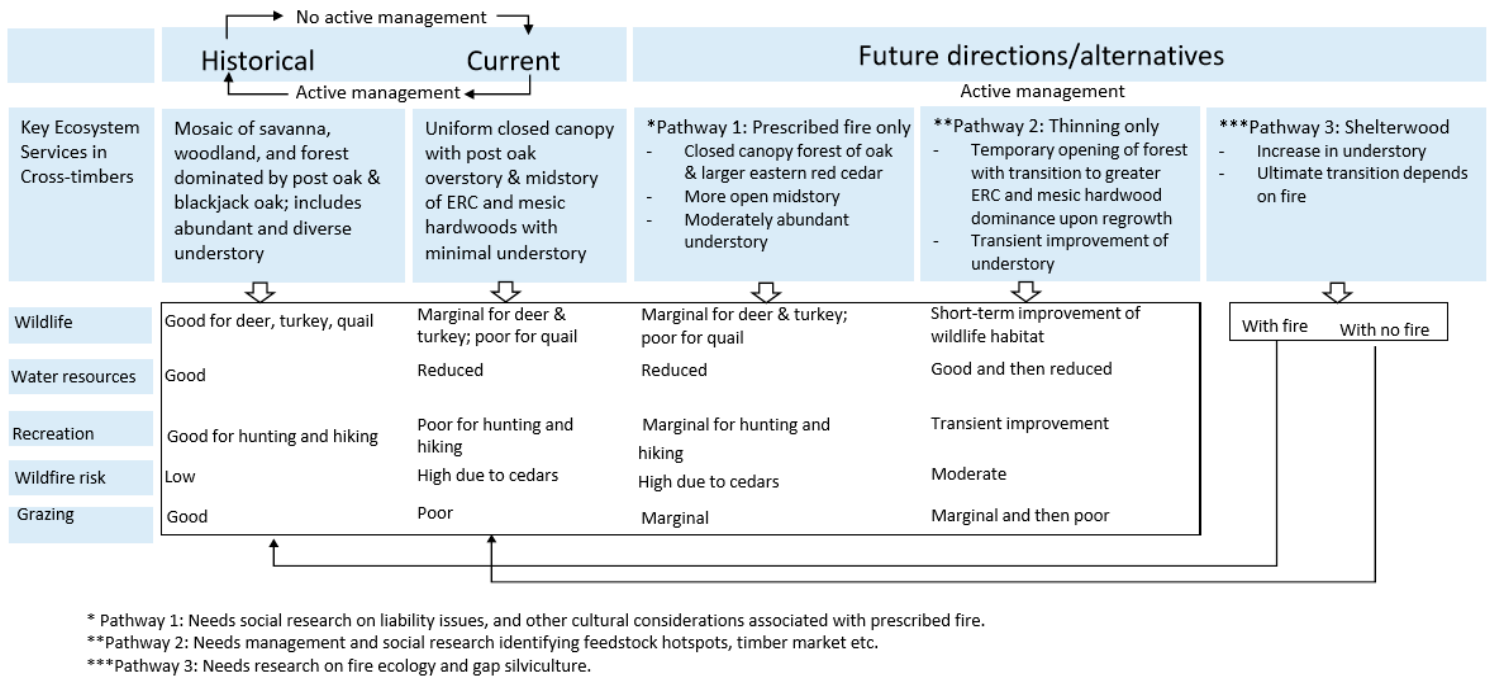

Figure A2. A conceptual framework showing historical and current state of active management and the possible future pathways.

\section{References}

1. Hallgren, S.W.; DeSantis, R.D.; Burton, J.A. Fire and vegetation dynamics in the Cross Timbers forests of south-central North America. In Proceedings of the 4th Fire in Eastern Oak Forests Conference, Springfield, MO, USA, 17-19 May 2011; Dey, D.C., Stambaugh, M.C., Clark, S.L., Schweitzer, C.J., Eds.; Gen. Tech. Rep. NRS-P-102; US Department of Agriculture, Forest Service, Northern Research Station: Newtown Square, PA, USA, 2012; pp. 52-66.

2. Küchler, A.W. Potential Natural Vegetation of the Conterminous United States: Manual to Accompany the Map; American Geographical Society: New York, NY, USA, 1964.

3. Bragg, D.C.; Stahle, D.W.; Cerny, K.C. Structural attributes of two old-growth Cross Timbers stands in western Arkansas. Am. Midl. Nat. 2012, 167, 40-56. [CrossRef]

4. Hoff, D.L.; Will, R.E.; Zou, C.B.; Lillie, N.D. Encroachment Dynamics of Juniperus virginiana L. and Mesic Hardwood Species into Cross Timbers Forests of North-Central Oklahoma, USA. Forests 2018, 9, 75. [CrossRef]

5. Therrell, M.; Stahle, D. A predictive model to locate ancient forests in the Cross Timbers of Osage County, Oklahoma. J. Biogeogr. 1998, 25, 847-854. [CrossRef]

6. Rice, E.L.; Penfound, W.T. The upland forests of Oklahoma. Ecology 1959, 40, 593-608. [CrossRef]

7. Starr, M.; Joshi, O.; Will, R.E.; Zou, C.B. Perceptions regarding active management of the Cross-timbers forest resources of Oklahoma, Texas, and Kansas: A SWOT-ANP analysis. Land Use Policy 2019, 81, 523-530. [CrossRef]

8. Engle, D.M.; Bidwell, T.G.; Moseley, M.E. Invasion of Oklahoma Rangelands and Forests by Eastern Redcedar and Ashe Juniper; Oklahoma Cooperative Extension Service, Division of Agricultural Sciences and Natural Resources, Oklahoma State University: Stillwater, OK, USA, 1996.

9. Engle, D.M.; Bodine, T.N.; Stritzke, J. Woody plant community in the cross timbers over two decades of brush treatments. Rangel. Ecol. Manag. 2006, 59, 153-162. [CrossRef]

10. Leslie, D.M., Jr.; Soper, R.B.; Lochmiller, R.L.; Engle, D.M. Habitat use by white-tailed deer on cross timbers rangeland following brush management. J. Range Manag. 1996, 49, 401-406. [CrossRef]

11. Hoff, D.L.; Will, R.E.; Zou, C.B.; Weir, J.R.; Gregory, M.S.; Lillie, N.D. Estimating increased fuel loading within the Cross Timbers forest matrix of Oklahoma, USA due to an encroaching conifer, Juniperus virginiana, using leaf-off satellite imagery. For. Ecol. Manag. 2018, 409, 215-224. [CrossRef]

12. Qiao, L.; Zou, C.B.; Stebler, E.; Will, R.E. Woody plant encroachment reduces annual runoff and shifts runoff mechanisms in the tallgrass prairie, USA. Water Resour. Res. 2017, 53, 4838-4849. [CrossRef]

13. Zou, C.B.; Turton, D.J.; Will, R.E.; Engle, D.M.; Fuhlendorf, S.D. Alteration of hydrological processes and streamflow with juniper (Juniperus virginiana) encroachment in a mesic grassland catchment. Hydrol. Process. 2014, 28, 6173-6182. [CrossRef] 
14. Van Els, P.; Will, R.E.; Palmer, M.W.; Hickman, K.R. Changes in forest understory associated with Juniperus encroachment in Oklahoma, USA. Appl. Veg. Sci. 2010, 13, 356-368.

15. Starr, M.; Joshi, O.; Will, R.E.; Zou, C.B.; Parajuli, R. Understanding Market Opportunities Utilizing the Forest Resources of the Cross-timbers Ecoregion. J. For. 2019, 117, 234-243. [CrossRef]

16. Butler, B.; Hewes, J.H.; Dickinson, B.J.; Andrejczyk, K.; Butler, S.M.; Markowski-Lindsay, M. USDA Forest Service National Woodland Owner Survey: National, Regional, and State Statistics for Family Forest and Woodland Ownerships with 10+ Acres, 2011-2013; Res. Bull. NRS-99; US Department of Agriculture, Forest Service, Northern Research Station: Newtown Square, PA, USA, 2016; 39p.

17. Wyckoff, D.G. The Cross Timbers: An Ecotone in Historic Perspective. Contributions to Cross Timbers Prehistory; Oklahoma Archeological Survey: Norman, OK, USA, 1984; pp. 1-20.

18. Francaviglia, R. Selling heritage landscapes. In Preserving Cultural Landscapes in America; Arnold, R.A., Robert, Z.M., Eds.; The Johns Hopkins University Press: Baltimore, MD, USA, 2000; pp. 44-69.

19. Allen, M.S.; Palmer, M.W. Fire history of a prairie/forest boundary: More than 250 years of frequent fire in a North American tallgrass prairie. J. Veg. Sci. 2011, 22, 436-444. [CrossRef]

20. Clark, S.L.; Hallgren, S.W.; Stahle, D.W.; Lynch, T.B. Characteristics of the Keystone Ancient Forest Preserve, an old-growth forest in the Cross Timbers of Oklahoma, USA. Nat. Areas J. 2005, 25, 165-175.

21. DeSantis, R.D.; Hallgren, S.W.; Stahle, D.W. Historic fire regime of an upland oak forest in south-central North America. Fire Ecol. 2010, 6, 45-61. [CrossRef]

22. Stambaugh, M.C.; Guyette, R.P.; Godfrey, R.; McMurry, E.; Marschall, J. Fire, drought, and human history near the western terminus of the Cross Timbers, Wichita Mountains, Oklahoma, USA. Fire Ecol. 2009, 5, 51-65. [CrossRef]

23. DeSantis, R.D.; Hallgren, S.W.; Lynch, T.B.; Burton, J.A.; Palmer, M.W. Long-term directional changes in upland Quercus forests throughout Oklahoma, USA. J. Veg. Sci. 2010, 21, 606-618. [CrossRef]

24. Stambaugh, M.C.; Sparks, J.; Guyette, R.P.; Willson, G. Fire history of a relict oak woodland in northeast Texas. Rangel. Ecol. Manag. 2011, 64, 419-423. [CrossRef]

25. Masters, R.E.; Waymire, J.R. Oak savanna restoration: Oak response to fire and thinning through 28 years. In Proceedings of the 4th Fire in Eastern Oak Forests Conference, Springfield, MO, USA, 17-19 May 2011; Dey, D.C., Stambaugh, M.C., Clark, S.L., Schweitzer, C.J., Eds.; Gen. Tech. Rep. NRS-P-102. US Department of Agriculture, Forest Service, Northern Research Station: Newtown Square, PA, USA, 2012; pp. 69-91.

26. DeSantis, R.D.; Hallgren, S.W.; Stahle, D.W. Drought and fire suppression lead to rapid forest composition change in a forest-prairie ecotone. For. Ecol. Manag. 2011, 261, 1833-1840. [CrossRef]

27. Rogers, T.R.; Russell, F.L. Historical patterns of oak population expansion in the Chautauqua Hills, Kansas. J. Biogeogr. 2014, 41, 2105-2114. [CrossRef]

28. Stambaugh, M.C.; Marschall, J.M.; Guyette, R.P. Linking fire history to successional changes of xeric oak woodlands. For. Ecol. Manag. 2014, 320, 83-95. [CrossRef]

29. Burton, J.A.; Hallgren, S.W.; Palmer, M.W. Fire frequency affects structure and composition of xeric forests of eastern Oklahoma. Nat. Areas J. 2010, 30, 370-379. [CrossRef]

30. Zou, C.B.; Qiao, L.; Wilcox, B.P. Woodland expansion in central Oklahoma will significantly reduce streamflows-a modelling analysis. Ecohydrology 2016, 9, 807-816. [CrossRef]

31. Karki, L.; Hallgren, S.W. Tree-fall gaps and regeneration in old-growth cross timbers forests. Nat. Areas J. 2015, 35, 533-541. [CrossRef]

32. Arévalo, J.R. Distribution of trees and saplings at the edge of Cross Timbers Forests, Oklahoma, USA. Nat. Areas J. 2002, 22, 99-107.

33. Rosson, J.F. Quercus stellata growth and stand characteristics in the Quercus stellata-Quercus marilandica forest type in the cross timbers region of central Oklahoma. In Proceedings of the North American Conference on Savannas and Barrens: Living on the Edge; Fralish, J.H., Anderson, R., Eds.; US Environmental Protection Agency, Great Lakes National Program Office: Chicago, IL, USA, 1994; pp. 329-333.

34. Johnson, F.L.; Risser, P.G. Biomass, annual net primary production, and dynamics of six mineral elements in a post oak-blackjack oak forest. Ecology 1974, 55, 1246-1258. [CrossRef]

35. Burton, J.A.; Hallgren, S.W.; Fuhlendorf, S.D.; Leslie, D.M. Understory response to varying fire frequencies after 20 years of prescribed burning in an upland oak forest. Plant Ecol. 2011, 212, 1513-1525. [CrossRef] 
36. Williams, R.J.; Hallgren, S.W.; Wilson, G.W. Frequency of prescribed burning in an upland oak forest determines soil and litter properties and alters the soil microbial community. For. Ecol. Manag. 2012, 265, 241-247. [CrossRef]

37. Scifres, C.J. Brush Management: Principles and PRACTICEs for Texas and the Southwest; Texas A \& M University Press: College Station, TX, USA, 1980; p. 360.

38. Engle, D.M.; Stritzke, J.F.; McCollum, F.T. Vegetation management in the Cross Timbers: Response of understory vegetation to herbicides and burning. Weed Technol. 1991, 5, 406-410. [CrossRef]

39. Schulz, C.A.; Leslie, D.M., Jr.; Lochmiller, R.L.; Engle, D.M. Herbicide effects on cross timbers breeding birds. J. Range Manag. 1992, 45, 407-411. [CrossRef]

40. Jones, B.; Fox, S.F.; Leslie, D.M., Jr.; Engle, D.M.; Lochmiller, R.L. Herpetofaunal responses to brush management with herbicide and fire. J. Range Manag. 2000, 53, 154-158. [CrossRef]

41. Bernardo, D.; Engle, D.; Lochmiller, R.; McCollum, F. Optimal vegetation management under multiple-use objectives in the Cross Timbers. J. Range Manag. 1992, 45, 462-469. [CrossRef]

42. Elmore, R.; Bidwell, T.; Weir, J. Perceptions of Oklahoma residents to prescribed fire. In Proceedings of the 24th Tall Timbers Fire Ecology Conference: The Future of Prescribed Fire: Public Awareness, Health, and Safety, Tall Timbers Research Station, Tallahassee, FL, USA, 1 January 2010.

43. Joshi, O.; Becerra, T.A.; Engle, D.M.; Fuhlendorf, S.D.; Elmore, R.D. Factors affecting public preferences for grassland landscape heterogeneity in the Great Plains. Environ. Manage. 2017, 60, 922-930. [CrossRef] [PubMed]

44. Joshi, O.; Poudyal, N.C.; Weir, J.R.; Fuhlendorf, S.D.; Ochuodho, T.O. Determinants of perceived risk and liability concerns associated with prescribed burning in the United States. J. Environ. Manag. 2019, 230, 379-385. [CrossRef] [PubMed]

45. Weir, J.R.; Engle, D.M. Cedar Control by Individual Schorched-tree Ignition Following Fire; Oklahoma State University. Division of Agricultural Sciences and Natural: Stillwater, OK, USA, 2017.

46. Clark, S.L.; Hallgren, S.W. Dynamics of oak (Quercus marilandica and Q. stellata) reproduction in an old-growth Cross Timbers forest. Southeast. Nat. 2003, 2, 559-574. [CrossRef]

47. de Groot, R.; Fisher, B.; Christie, M.; Aronson, J.; Braat, L.; Gowdy, J.; Haines-Young, R.; Maltby, E.; Neuville, A.; Polasky, S.; et al. Integrating the ecological and economic dimensions in biodiversity and ecosystem service valuation. In The Economics of Ecosystems and Biodiversity: The Ecological and Economic Foundations; Kumar, P., Ed.; Routledge: London, UK, 2010.

48. Niazi, M.; Hussain, A.J.S. Agent-based computing from multi-agent systems to agent-based models: A visual survey. Scientometrics 2011, 89, 479. [CrossRef]

49. Joshi, O.; Mehmood, S.R. Segmenting southern nonindustrial private forest landowners on the basis of their management objectives and motivations for wood-based bioenergy. South. J. Appl. For. 2011, 35, 87-92. [CrossRef]

(C) 2019 by the authors. Licensee MDPI, Basel, Switzerland. This article is an open access article distributed under the terms and conditions of the Creative Commons Attribution (CC BY) license (http://creativecommons.org/licenses/by/4.0/). 